\title{
Platelet Rich Plasma Give Promising Results in Chronic Wound Healing
}

\section{Niyati Dhawan and Brajpal Singh Tyagi*}

Department of ENT, Columbia Asia Hospital Ghaziabad, CEO Harsh ENT Hospital, Centre for Deafness, ABR Health Care Solutions Limited, India

*Corresponding Author: Brajpal Singh Tyagi, Professor, Head, Department of ENT, Columbia Asia Hospital Ghaziabad, CEO Harsh ENT Hospital, Centre for Deafness, ABR Health Care Solutions Limited, India.
Received: May 16, 2020

Published: June 18, 2020

(C) All rights are reserved by Niyati Dhawan and Brajpal Singh Tyagi.

\section{Abstract}

We have treated two cases of non-healing wound after radiation.

One is Pharyngo cutaneous fistula - Pharyngo Cutaneous Fistula (PCF) is the communication of the digestive tract with the cervical skin which originates the appearance of saliva on the skin surface after swallowing.

Second is the post-operative metastatic lymph node excision from left side of neck.

The PRP and PRP Gel works better in this kind of cases. We are submitting reports from our center.

Keywords: Platelet Rich Plasma (PRP); Chronic Wound Healing

\section{Objective of the Study}

To check the efficacy the platelet rich plasma (PRP) and PRP Gel in wound healing.

\section{Materials and Methods}

PRP Machine, ACD vacutainer, blood collection kit.

As we all know PRP is full of growth factors and we have so many papers on that topic.

The major factors are:

- Platelet-rich plasma also known as autologous platelet rich plasma protein derived from whole blood.

- Platelet derived growth factor

- Transforming growth factor beta

- Fibroblast growth factor

- Insulin-like growth factor 1, insulin-like growth factor

- Vascular endothelial growth factor

- $\quad$ Epidermal growth factor

- Keratinocyte growth factor

- $\quad$ Interleukin 8

- Connection tissue growth factor.

\section{Result}

We are presenting two post-operation cancer patients:

1. Laryngeal pharyngeal fistula healed by PRP injection.

2. Deep non-healing wound left level 5 of neck healed by PRP injection. Images of both cases attached for review.

Case 1 


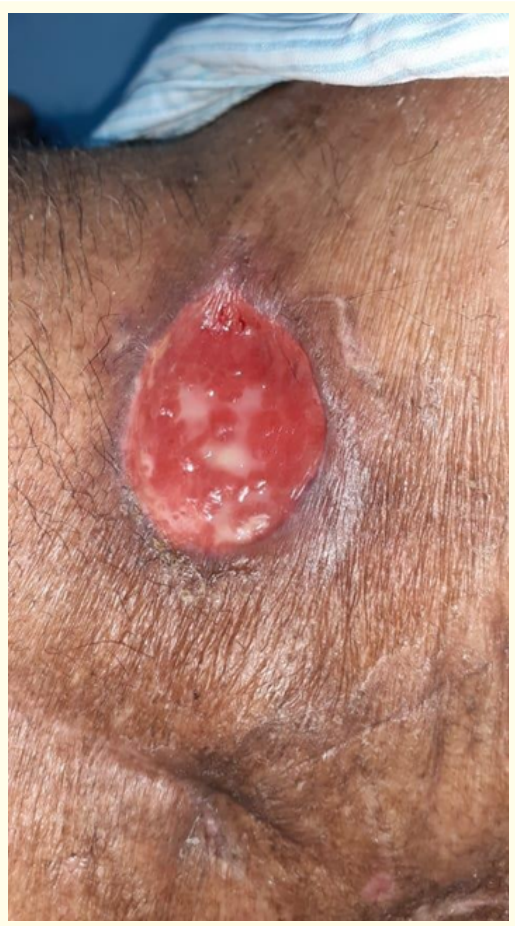

Figure 2: Post-PRP

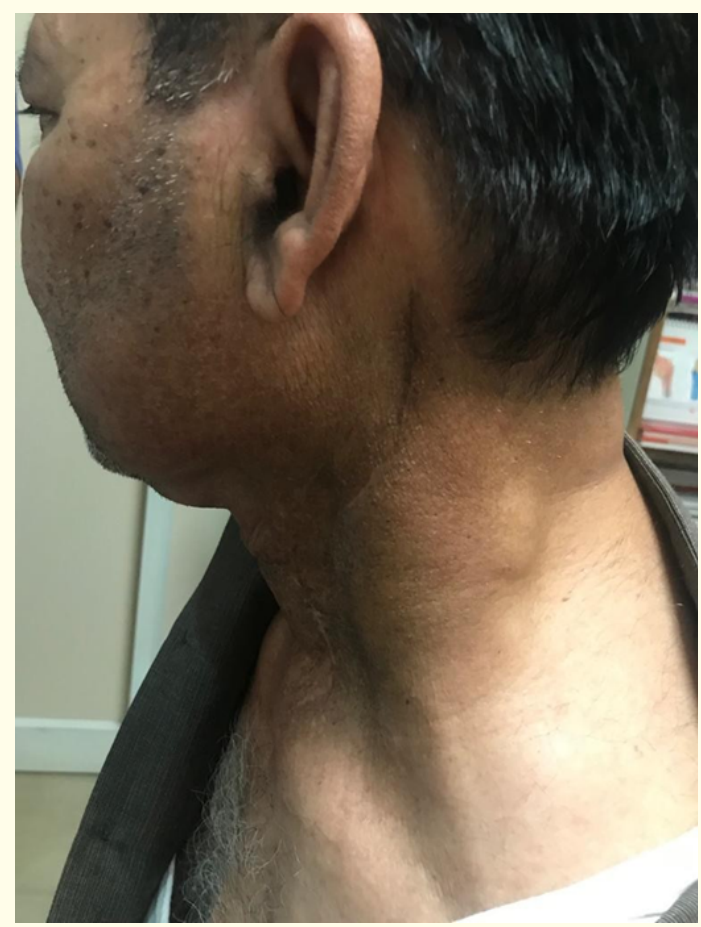

Figure 3: Final
Case 2

\section{PRE-PRP}

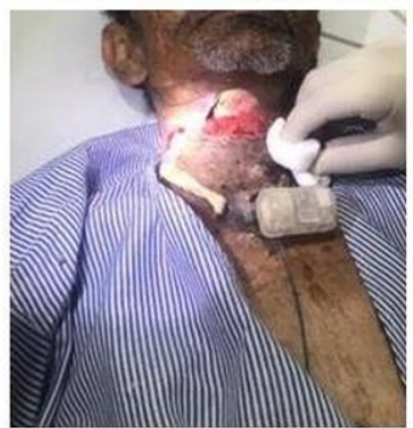

\section{POST-PRP}

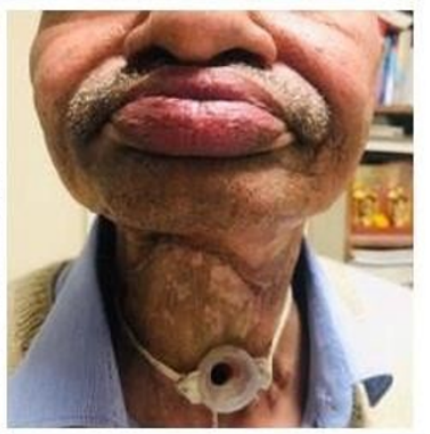

Figure 4

\section{Conclusion}

PRP is a promising agent for healing of post-radiation fistula and post-radiation non-healing wound [1-3].

\section{Bibliography}

1. Jorge L Alio., et al. "The Role of "Eye Platelet Rich Plasma (EPRP) for wound Healing in Ophthalmology". Current Pharmaceutical Biotechnology 13.7 (2011): 1257-1265.

2. Cihad Tatar., et al. "The effects of platelet-rich plasma on wound healing in rats". International Journal of Clinical and Experimental Medicine 10.5 (2017): 7698-7706.

3. Ugur Yildirim., et al. "Effects of submucosal PRP injection on wound healing in Endonasal surgeries: an experimental study". European Archives of Oto-Rhino-Laryngology 277.6 (2020): 1681-1689.

\section{Assets from publication with us}

- Prompt Acknowledgement after receiving the article

- Thorough Double blinded peer review

- Rapid Publication

- Issue of Publication Certificate

- High visibility of your Published work

Website: https://www.actascientific.com/

Submit Article: https://www.actascientific.com/submission.php Email us: editor@actascientific.com

Contact us: +919182824667 